\title{
TINDAK TUTUR KOMISIF PADA BALIHO CALON WALI KOTA DAN WAKIL WALI KOTA TERNATE TAHUN 2020
}

\author{
Sasmayunita \\ Universitas Khairun, Ternate, Indonesia \\ mrsasmayunita@yahoo.com
}

\begin{abstract}
This study examines the problem of commissive speech acts in candidates for mayor and deputy mayor of Ternate in 2020. The purpose of this study is to describe the form of commissive speech acts on billboards for candidates for mayor and deputy mayor of Ternate in 2020. This type of research is descriptive qualitative. The data source is the discourse on the billboards for the 2020 Mayor and Deputy Mayor of Ternate. The technique of collecting is through observation, documentation, and taking notes. The data analysis technique in this study is the content analysis method by examining all data from various sources according to observations, documentation, and listening results (notes). Next, sort, analyze, and describe the forms of commissive speech acts and conclude the findings. The findings show several forms of commissive speech acts: commissive speech acts of intention, promise, and commissive speech acts of offering. This study recommends that further researchers conduct studies on different objects with a broader amount of data.
\end{abstract}

Keywords: commissive speech acts, discourse analysis, speech acts

\begin{abstract}
ABSTRAK
Penelitian ini mengkaji masalah tindak tutur komisif pada calon Wali Kota dan Wakil Wali Kota Ternate tahun 2020. Tujuan dari penelitian ini untuk mendeskripsikan bentuk tindak tutur komisif pada baliho calon Wali Kota dan wakil Wali Kota Ternate tahun 2020. Jenis penelitian ini adalah deskriptif kualitatif. Sumber data ialah wacana pada baliho calon Wali Kota dan Wakil Wali Kota Ternate yang dilaksanakan pada Tahun 2020. Teknik pengumpulan melalui observasi, dokumentasi, dan mencatat. Teknik analisis data pada penelitian ini adalah metode analisis isi dengan menelaah seluruh data dari berbagai sumber sesuai dengan hasil pengamatan, dokumentasi, dan hasil menyimak (mencatat). Selanjutnya, memilah, menganalisis, dan mendeskripsikan bentuk-bentuk tindak tutur komisif, dan menyimpulkan data temuan. Hasil temuan menunjukkan beberapa bentuk tindak tutur komisif pada baliho calon Wali Kota dan Wakil Wali Kota Ternate tahun 2020, antara lain: tindak tutur komisif berniat, berjanji, dan tindak tutur komisif menawarkan. Hasil dari penelitian ini merekomendasikan kepada peneliti lanjut untuk melakukan kajian pada objek yang berbeda dengan jumlah data yang lebih luas.
\end{abstract}

Kata kunci: analisis wacana, tindak tutur, tindak tutur komisif 


\section{PENDAHULUAN}

Manusia merupakan makhluk sosial yang dapat berinteraksi, mengekspresikan suatu gagasan, menyatakan pendapat, maupun memengaruhi suatu hal dengan orang lain. Manusia dalam berinteraksi dan menyatakan suatu pendapat dilakukan melalui bahasa untuk saling memahami satu sama lain. Sementara itu, Kridalaksana (2011) mengemukakan bahasa adalah sistem lambang bunyi yang arbiter digunakan oleh para anggota kelompok sosial untuk bekerja sama, berkomunikasi, dan mengidentifikasi diri. Bahasa merupakan sistem lambang bunyi yang digunakan oleh suatu masyarakat untuk berkomunikasi, tidak dapat dibayangkan apa yang terjadi apabila manusia tidak memiliki bahasa. Selain itu, komunikasi yang dilakukan dapat mempererat hubungan sosial antara satu penutur dengan penutur lainnya untuk bisa saling memahami . Oleh karena itu, bahasa tidak terlepas dari kehidupan manusia. Pernyataan tersebut sejalan dengan pendapat (Basri et al., 2021; A. Alber \& Febria, 2018; dan \{Formatting Citation $\}$.

Bahasa dapat digunakan untuk menyampaikan ideologi untuk memengaruhi cara berpikir seseorang atau dapat digunakan untuk mengendalikan pikiran orang lain. Selain itu, komunikasi ialah suatu proses dalam menyampaikan pesan antara penutur dan mitra tutur yang memiliki kesamaan makna tentang pesan yang disampaikan. Oleh sebab itu, untuk memahami dan mempelajari bahasa dibutuhkan disiplin ilmu yang mampu menjabarkan bentuk bahasa sesuai dengan konteksnya. Kegiatan berkomunikasi tidak hanya dilakukan melalui lisan, namun komunikasi dapat juga dilakukan melalui media, seperti halnya contoh tulisan pada baliho atau spanduk Calon Wali Kota dan Wakil Wali Kota Ternate.

Baliho atau spanduk merupakan media yang digunakan untuk berkomunikasi dan menyampaikan sesuatu, serta suatu cara untuk pengenalan terhadap Calon Wali dan Wakil Wali Kota. Sutarini (2019) mengemukakan bahwa baliho merupakan alat yang digunakan dalam menyampaikan suatu informasi secara visual mengenai adanya suatu agenda kegiatan untuk dapat dilihat oleh kalangan masyarakat. Fungsi dari baliho ialah untuk untuk menyampaikan aspirasi, gagasan, atau pesan yang melalui tulisan dan gambar agar dapat menarik perhatian pembaca. Irawan (2012) menguungkapkan bahwa sebagaian besar baliho juga digunakan untuk kegiatan kampanye oleh suatu partai politik atau kandidit kepala daerah.

Baliho dan spanduk merupakan salah satu cara untuk memperkenalkan figur calon Wakil dan Wali Kota. Para calon Wali dan Wakil Wali Kota mencitrakan diri mereka melalui kata-kata maupun dalam bentuk gambar. Hal tersebut diungkapkan dengan suatu maksud menggunakan kata-kata yang menarik dan terkesan meyakinkan masyarakat. Tujuannya untuk menarik perhatian masyarakat agar memilih calon Wali dan Wakil Wali Kota untuk menduduki kursi sebagai pemimpin kepala daerah. Oleh karena itu, dibutuhkan kerja keras untuk mempromosikan diri dengan berbagai kegiatan melalui kampanye, salah satunya melalui media gambar.

Pemakaian bahasa pada iklan, khususnya pada wacana spanduk di wilayah Ternate tidak terlepas dari maksud menggunakan bahasa sebagai proses untuk menarik simpati masyarakat agar terpilih menjadi pemimpin di Kota Ternate. Bahasa dalam wacana spanduk merupakan hal yang sangat menarik untuk diteliti. Pemilihan data wacana pada baliho di kota Ternate karena mempunyai daya tarik yang sangat tinggi bagi pembaca dengan menggunakan bahasa iklan yang sangat menarik. Pada penelitian ini, penulis memilih pemakaian tindak tutur komisif pada baliho di wilayah Ternate sebagai objek kajian. Hal ini didasarkan karena sebagian besar wacana baliho Calon Wali dan Wakil Wali Kota di kota Ternate 
mengandung unsur yang memiliki tujuan untuk menawarkan atau menjanjikan sesuatu, sehingga menarik untuk menjadi kajian penelitian.

Tindak tutur komisif merupakan bentuk tindak tutur yang digunakan untuk meyakinkan tuturan penutur pada mitra tutur. Purba (2011) dan Saifudin (2019) mengemukakan bahwa tindak tutur komisif ialah suatu bentuk tindak tutur yang menyatakan bahwa suatu penutur telah melakukan sesuatu atau berkomitmen untuk suatu tindakan, seperti adanya janji atau ancaman. Tindak tutur komisif menuturkan tentang tindakan yang akan dilakukan di masa yang akan datang. Pada tindak tutur komisif penutur sedikit banyak terikat pada suatu tindakan di masa depan. Jenis tindak tutur komisif disini meliputi tindak tutur komisif berjanji, berniat, bersumpah dan menawarkan. Kemenarikan juga terdapat pada pemakaian kata, maksud ujaran atau kalimat yang digunakan dalam wacana spanduk Calon Wali dan Wakil Wali Kota Ternate. Oleh Karena itu, penulis menjadikan tulisan pada baliho Calon Wali Kota dan Wakil Wali Kota Ternate sebagai objek penelitian untuk dikaji lebih mendalam mengenai tindak tutur komisif dengan menggunakan analisis wacana kritis.

Tindak tutur ialah tindakan yang ditampilkan dengan menghasilkan suatu tuturan. Sebagaimana pendapat yang dikemukakan Izhar \& Seftika (2020) bahwa tindak tutur telah membahas tentang keserasian antara tuturan dan tindakan yang digunakan saat berkomunikasi dengan konteks tuturan yang bersifat sensitif. Yule (2006) mengelompokkan tiga bentuk tindak tutur yang yang saling berhubungan, yaitu: tindak tutur lokusi, tindak tutur ilokusi, dan tindak tutur perlokusi.

Penelitian tentang tindak tutur maupun analisis terhadap wacana pada baliho sudah diteliti oleh beberapa peneliti sebelumnya. Seperti penelitian yang dilakukan Swashaning (2015) dengan judul penelitian Tindak Tutur Komisif dalam Komik Tintin Edisi 1960 - 1976
Karya Herge. Hasil penelitian mengungkapkan bahwa tuturan komisif dalam komik Tintin terbagi menjadi dua yaitu promises (menjanjikan), dan offer (menawarkan). Adapun fungsi dari tuturan komisif dalam komik tersebut ialah: bertaruh, bersumpah, mengundang, mengusulkan, dan menawarkan pengabdian.

Selanjutnya penelitian tentang bentuk dan fungsi tidak tutur slogan varian iklan pada media massa dilakukan oleh Ananda et al., (2015). Hasil penelitian mengungkapkan bahwa dari 20 slogan yang diteliti, 18 slogan di antaranya mengandung fungsi tindak tutur komisif dan 2 slogan mengandung fungsi tindak tutur direktif. Dengan demikian, disimpulkan bahwa bentuk tindak tutur slogan yang dominan adalah deklaratif tidak langsung dan fungsi tindak tutur yang dominan adalah komisif. Hasil penelitian tersebut, juga tidak jauh berbeda dengan temuan Hardita (2019) yang mengkupkan bahwa ditemukan 20 data tindak tutur pada iklan bersoda melalui media televisi. Dari 20 data tersebut terdapat tindak tutur perlokusi direktif. Adapun makna dari tindak tutur perlokusi yang ditemukan dalam iklan produk minuman bersoda di televisi meliputi makna perintah,memberikan saran atau nasehat, dan makna menyatakan.

Kusno (2015) melakukan penelitian tentang Makna Bahasa Propaganda dalam Wacana (Spanduk dan Baliho) Tuntutan Otonomi Khusus Provinsi Kalimantan Timur (Kajian Semiotik). Hasil penelitian menunjukkan bahwa wacana propaganda tersebut mewakili isu tuntutan otonomi khusus yang disuarakan oleh satuan kerja Pemerintah Provinsi Kalimantan Timur, pemerintah kabupaten/kota, maupun berbagai organisasi kemasyarakatan. Penelitian sejenis juga dilakukan Purnengsih (2017) tentang Makna dan Pesandalam Baliho Pemilu Legislatif 2014. Membangun pemaknaan pada desain baliho, terdapat tiga komponen yang dikaji, mencakup: imaji konotatif, teks linguistik, dan 
imaji denotatif. Hasil temuan memaparkan bahwa representasi para caleg dalam baliho melalui berbagai simbol, seperti: simbol agama, pendidikan, status sosial, maupun nasionalisme.

Hasil penelitian Mhd. Virzha Nafandri Utama, \& Charlina (2021) juga memberikan suatu gambaran bahwa berbagai spanduk di Kota Pekanbaru memiliki makna positif dari sudut pandang tuturan imperatif. Hasil penelitian membuktikan bahwa tuturan tersebut mencakup suruhan, permintaan, bujukan, dan ajakan. Kempat tuturan imperatif tersebut bermakna positif.

Berdasarkan uraian di atas, tampak bahwa penelitian ini cukup menarik untuk dikaji secara mendalam tentang tindak tutur komisif pada baliho calon Wali Kota dan Wakil Wali Kota di Kota Ternate. Selain itu, beberapa penelitian sebelumnya juga menjadi acuan dalam penelitian ini. Namun, dari hasil kajian terhadap beberapa penelitian relevan bahwa terdapat beberapa perbedaan dengan penelitian.

\section{METODOLOGI PENELITIAN}

Penelitian ini bersifat kualitatif dengan menekankan pada masalah proses dan makna. Sebagaimana pendapat yang dikemukakan oleh Moleong (2007) bahwa penelitian kualitatif ialah bentuk penelitian yang dialami oleh subjek penelitian, seperti perilaku maupun tindakan secara deskriptif dalam bentuk bahasa dengan memanfaatkan metode secara ilmiah. Pernyataan tersebut senada dengan pendapat (Alber, 2017; Alber \& Rahayu, 2017; dan Suriadiman \& Anita, 2021). Hasil temuan penelitian dideskripsikan secara kualitatif sesuai dengan hasil analisis. Sumber data dalam penelitian ini berupa wacana pada baliho calon Wali Kota dan Wakil Wali Kota Ternate tahun 2020.

Pengumpulan data dilakukan melalui observasi, dokumentasi, dan teknik mencatat. Observasi (pengamatan) dan dokumentasi dilakukan untuk mengamati secara langsung baliho calon Wali Kota dan Wakil Wali Kota yang ada di Kota Ternate, sedangkan teknik catat dilakukan untuk mengidentifikasi wujud penggunaan bahasa dan isi pesan yang terkandung dalam tindak tutur komisif pada baliho calon Wali Kota dan Wakil Wali Kota Ternate tahun 2020.

Analisis data dilakukan dengan menelaah seluruh data dari berbagai sumber sesuai dengan hasil pengamatan, dokumentasi, dan hasil menyimak (mencatat). Selanjutnya, memilah, menganalisis, dan mendeskripsikan bentuk-bentuk tindak tutur komisif yang ada pada baliho calon Wali Kota dan Wakil Wali Kota Ternate tahun 2020. Tahap terakhir setelah proses analisis ialah menyimpulkan data temuan.

\section{HASIL DAN PEMBAHASAN}

Penelitian ini membahas mengenai tindak tutur komisif pada baliho calon Wali Kota dan Wakil Wali Kota Ternate tahun 2020. Berikut merupakan data dari tindak tutur komisif serta hasil analisis wacana pada baliho calon Wali Kota dan Wakil Wali Kota Ternate.

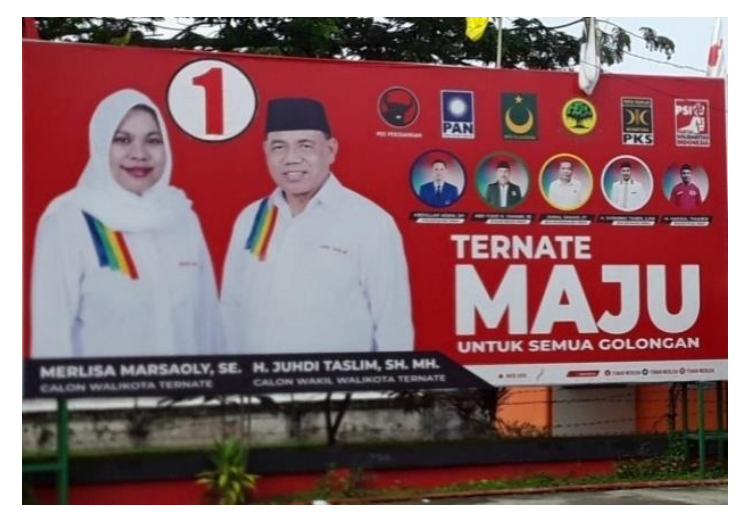

Gambar 1. Baliho Calon Wali Kota dan Wakil Wali Kota No. 1

Data 1. Ternate Maju untuk Semua Golongan

Data 2. Ternate Lebih Baik untuk Seluruh Masyarakat

Data tuturan (1) menyatakan tindak tutur komisif berniat "Ternate Maju untuk Semua Golongan". Adapun data tuturan (2) juga 
menyatakan tindak tutur komisif yang diucapkan secara lisan "Ternate Lebih Baik untuk Seluruh Masyarakat".

Kedua data tuturan pasangan calon Wali Kota Ternate mengikat penuturnya dengan berkhidmat jika mereka terpilih sebagai Wali Kota Ternate, mereka akan memajukan Ternate untuk semua golongan tanpa membedakan strata sosial. Baik golongan atas maupun menengah ke bawah. Hal ini mempunyai konsekuensi bagi dirinya untuk memenuhi tuturanya. Maksud dari tuturan tersebut adalah seorang pemimpin harus bisa memajukan semua golongan masyarakat agar tercipta rasa keadilan di antara mereka sehingga terjalin hubungan kedekatan antara pemimpin dengan rakyat. Demikian, cara pemimpin agar lebih mudah memahami amanah rakyat. Artinya pemimpin akan lebih cermat mendalami permasalahan yang diinginkan masyarakat sehingga untuk membawa amanah masyarakat diperlukan seorang pemimpin untuk lebih dekat dengan semua golongan. Hasil temuan ini sesuai dengan pendapat yang dikemukakan Purba (2011) dan Saifudin (2019) bahwa tindak tutur komisif menekankan pada komitmen terhadap suatu tindakan.

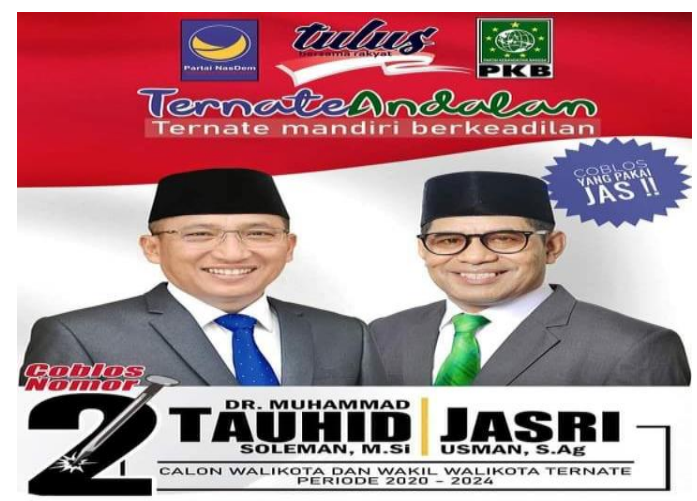

Gambar 2. Baliho Calon Wali Kota dan Wakil Wali Kota No. 2

Data 3. Tulus Bersama Rakyat, Ternate Andalan Ternate Mandiri dan Berkeadilan

Data 4. Tulus Mengabdi Kepada Rakyat

Data 5. Tulus Bersama Tauhid Jasri dalam Memimpin Ternate

Data pada tuturan (3) menyatakan tindak tutur komisif berjanji "Tulus" adalah
Akronim dari Tauhid Soleman dan Jasri Usman. Selanjutnya "Bersama rakyat, Ternate Andalan Ternate Mandiri Berkeadilan". Adapun data tuturan (4) dan (5) juga menyatakan tindak tutur komisif yang diucapkan secara lisan "Tulus Mengabdi Kepada Rakyat" dan "Tulus Bersama Tauhid Jasri dalam Memimpin Ternate".

Kandidat pasangan calon Wali Kota dan Wakil Wali Kota Ternate berjanji jika bersama pasangan calon Wali dan Wakil Wali Kota no urut 2, kandidat tersebut akan membangun Ternate yang tulus mengabdi, mandiri, dan berkeadilan. Maksud berkeadilan pada wacana tersebut ialah jangan sampai ada masyarakat yang tidak dilayani hak dasarnya untuk hidup di Kota Ternate. Tuturan tersebut mengikat penuturnya untuk berjuang demi kesejahteraan rakyat dengan menunjukkan kepedulian dan keadilan terhadap rakyatnya dengan melindungi rakyat, serta mengayomi rakyat agar sejalan untuk mencapai tujuan sebuah pemerintahan dengan sebaik-baiknya. Hasil penelitian ini juga sejalan dengan temuan Purnengsih (2017) tentang Makna dan Pesan dalam Baliho Pemilu Legislatif 2014 yang mengungkapkan bahwa salah satu representasi calag dalam baliho ialah menghadirkan simbol nasionalisme.

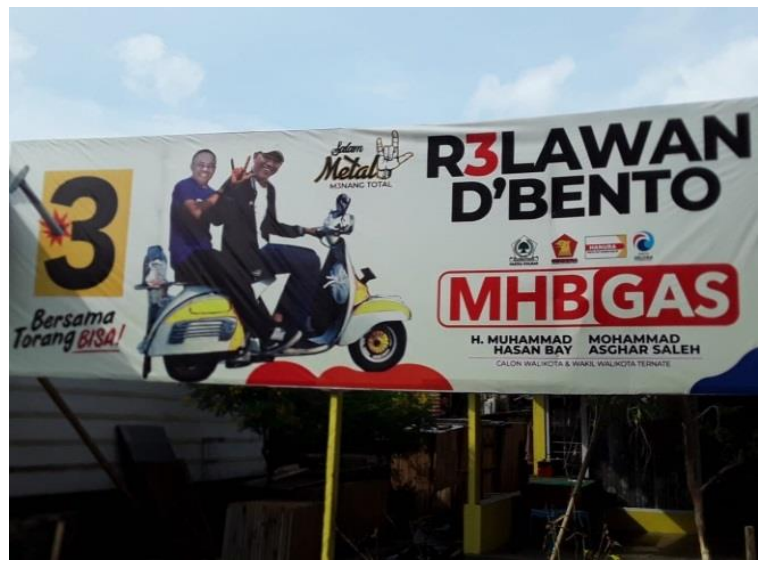

Gambar 3. Baliho Calon Wali Kota dan Wakil Wali Kota No. 3

Data 6. Bersama Torang Bisa

Data 7. Bersama MHB GAS Ternate Bisa

Data pada tuturan (6) menyatakan tindaktuturkomisif menawarkan "Bersama Torang Bisa". Adapun data tuturan (7) juga 
menyatakan tindak tutur komisif yang diucapkan secara lisan "Bersama MHB GAS Ternate Maju". Kedua tuturan tersebut mengikat penutur untuk melaksanakan tawarannya, torang (bahasa Melayu Ternate) yang artinya "kita" dengan memilih pemimpin tersebut mereka bersama rakyat bisa memajukan kota Ternate. Tuturan tersebut telah diperjelas secara lisan bahwa bersama MHB GAS Ternate bisa lebih maju.

Hal ini membawa konsekuensi bagi dirinya untuk memenuhi apa yang telah dituturkannya kepada masyarakat, bahwa jika bersama dengan pasangan calon Wali Kota dan Wakil Wali Kota Ternate no urut 3, Kota Ternate bisa bergerak dalam berbagai aspek. Hasil penelitian ini sejalan dengan temuan Swashaning (2015) bahwa salah satu fungsi dari tuturan komisif dalam komik Tintin ialah menawarkan pengabdian suatu pengabdian.

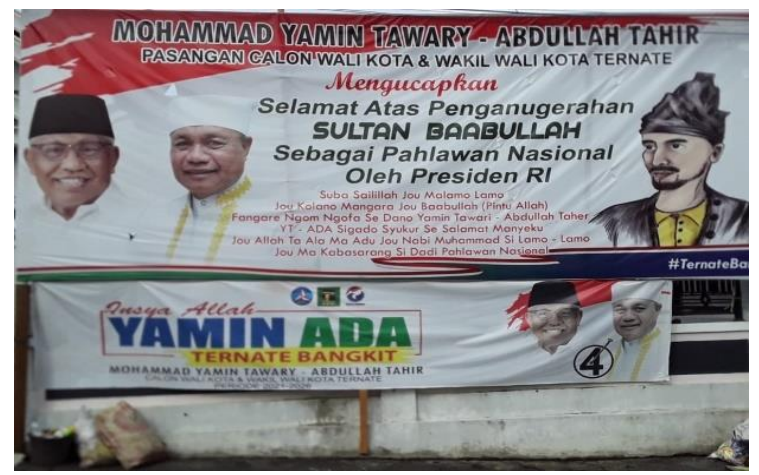

Gambar 4. Baliho Calon Wali Kota dan Wakil Wali Kota No. 4

Data 8. Insha Allah Yamin Ada Ternate Bangkit Data 9. Bersama Yamin Ternate Bisa Bangkit Data 10. Insya Allah Yamin Abdullah Ternate Lebih Maju

Data pada tuturan (8) menyatakan tindak tutur komisif menawarkan "Insha Allah Yamin Ada Ternate Bangkit". Adapun data tuturan (9) dan (10) juga menyatakan tindak tutur komisif yang diucapkan secara lisan "Bersama Yamin Ternate Bisa Bangkit" dan "Insya Allah Yamin Abdullah Ternate Lebih Maju".

Tuturan ini mengikat penutur untuk melaksanakan tawarannya, kata Insha Allah (bahasa Arab) yang artinya "jika Allah mengizinkan". Selanjutnya pada data tuturan 8 yang telah dipertegas secara lisan bahwa "Bersama Yamin Ternate Bisa Bangkit". Dengan demikian, jika memilih pemimpin tersebut bisa dipastikan Ternate bangkit, maju, dan sejahtera. Hal ini membawa konsekuensi bagi dirinya untuk memenuhi apa yang telah dituturkannya. Hasil penelitian ini juga sejalan dengan temuan Purnengsih (2017) tentang Makna dan Pesan dalam Baliho Pemilu Legislatif 2014 yang mengungkapkan bahwa salah satu representasi calag dalam baliho ialah menghadirkan simbol agama.

\section{SIMPULAN}

Pemakaian bahasa pada iklan khususnya pada wacana baliho di Ternate, tidak terlepas dari maksud dan tujuan bahasa itu digunakan dalam proses untuk merebut hati dan simpati khalayak para calon pemilih supaya memilih calon kandidatnya pada pemilihan Calon Wali dan Wakil Wali Kota Ternate. Wacana pada baliho di daerah Ternate mempunyai daya tarik yang sangat tinggi bagi pembaca dan memiliki bahasa iklan yang menarik untuk dikaji. Hasil penelitian yang telah diuraikan dapat disimpulkan bahwa terdapat tiga jenis tuturan yang ditemukan pada penelitian ini yang mencakup tindak tutur berniat, berjanji, dan menawarkan. Olehnya itu, diharapkan pembaca atau masayarakat tidak keliru dalam menentukan pilihan Wali Kota dan Wakil Wali Kota agar di masa mendatang akan memiliki pemimpin hasil dari pilihan Masyarakat dan tentu saja dengan pilihan Wali Kota dan Wakil Wali Kota yang benar-benar dapat dipercaya atas tuturannya, janjinya, dan sumpahnya untuk masyarakat.

\section{REFERENSI}

Alber, A. (2017). Morfofonemik dalam Pantun Tunjuk Ajar Melayu Karya Tenas Effendy. Konferensi Linguistik Tahunan Atma Jaya 15. https://lib.atmajaya.ac.id/default.aspx?

Alber, A., \& Febria, R. (2018). Analisis Kesalahan Berbahasa Tataran Sintaksis dalam Kumpulan Makalah Mahasiswa Universitas Islam Riau. GERAM, 6(2). https://doi.org/https://doi.org/10.25299/ger am.2018.vol6(2).2143

Alber, A., \& Rahayu, S. (2017). Kohesi Teks 
Syair dalam Tunjuk Ajar Melayu Karya Tenas Effendi. GERAM (Gerakan Aktif Menulis), 5(1), 58-65. https://doi.org/https://doi.org/10.25299/ger am.2017.vol5(1).421

Ananda, N. A., Sutama, I. M., \& Nurjaya, I. G. (2015). Bentuk dan Fungsi Tindak Tutur Slogan Varian Iklan Pond's di Televisi Swasta. JJPBS Universitas Pendidikan Ganesha, Jurusan Pendidikan Dan Sastra Indonesia, 3, NO. 1(1), 1--12.

Basri, M. S., Safitri, H., \& Hakim, M. N. (2021). Kesantunan Berbahasa: Studi pada Pembelajaran Daring. Jurnal Onoma: Pendidikan, Bahasa, Dan Sastra, 7(1), 242-248. https://doi.org/10.30605/onoma.v7i1.625

Hardita, R. P. (2019). Analisis Tindak Tutur Perlokusi pada Iklan Minuman Bersoda Ditelevisi.

Irawan, J. (2012). Permasalahan dan Solusi Konstruksi Baliho di Banjarmasin. Jurnal Poros Teknik, 4(2).

Izhar, I., \& Seftika, S. (2020). Tindak Tutur dalam Tinjauan Filsafat Bahasa. Anterior Jurnal, 20(1), 78-82. https://doi.org/10.33084/anterior.v20i1.152 8

Kridalaksana. (2011). Kamus Linguistik. Jakarta: Gramedia Pustaka.

Kusno, A. (2015). Makna Bahasa Propaganda dalam Wacana (Spanduk dan Baliho) Tuntutan Otonomi Khusus Provinsi Kalimantan Timur (Kajian Semiotik). PAROLE: Journal of Linguistics and Education, $\quad 5(1), \quad 40$. https://doi.org/10.14710/parole.v5i1.8647

Mhd. Virzha Nafandri Utama, Charlina, E. S. (2021). Tuturan Imperatif Bermakna Positif pada Spanduk di Kota Pekanbaru. GERAM (Gerakan Aktif Menulis), 9(1), 17-23.

Moleong, L. J. (2007). Metodologi Penelitian Kualitatif. Bandung: PT. Remaja Rosdakarya.

Purba, A. (2011). Tindak Tutur dan Peristiwa Tutur. Pena: Jurnal Pendidikan Bahasa Dan Sastra, 1(1), 77-91.

Purnengsih, I. (2017). Makna dan Pesan dalam Baliho Pemilu Legislatif 2014. Jurnal Desain, 4(03), 231. https://doi.org/10.30998/jurnaldesain.v4i03 .1604

Safitri, R. N., Auzar, \& Hermandra. (2021). Perbedaan Kosakata Dialek Melayu di Desa Betung dengan Desa Kesuma Kecamatan Pangkalan Kuras kabupaten Pelalawan. GERAM (Gerakan Aktif Menulis), 9(1), 65-73. https://doi.org/https://doi.org/10.25299/ger am.2021.vol9(1).6799

Saifudin, A. (2019). Teori Tindak Tutur dalam Studi Linguistik Pragmatik. Lite: Jurnal Bahasa, Sastra, Dan Budaya, 5(1), 1-16.

Suriadiman, N., \& Anita, F. (2021). Pemerolehan Bahasa Anak Usia 4 Tahun (Studi Kajian Morfologi) di Paud Sahira Kota Pekanbaru Provinsi Riau. GERAM (Gerakan Aktif Menulis), 9(1), 56-64. https://doi.org/https://doi.org/10.25299/ger am.2021.vol9(1).6512

Sutarini, I. A. (2019). Pengukuran Efektivitas Penggunaan Media Baliho Pada Pemilihan Umum 2019 Terhadap Generasi Milenial. SENADA (Seminar Nasional Desain Dan Arsitektur), 2, 237-241.

Swashaning, L. (2015). Tindak Tutur Komisif dalam Komik Tintin Edisi 1960-1976 Karya Herge. Universitas Negeri Yogyakarta.

Yule, G. (2006). Pragmatik. Yogyakarta: Pustaka Pelajar. 